\title{
Recommendations for Promoting a Performative Teaching, Learning, and Research Culture in Higher Education
}

\author{
Bärbel Jogschies, Manfred Schewe, Anke Stöver-Blahak
}

The twenty-first century is the century of the performative. ${ }^{1}$ Claire Colebrook (2018)

A performative teaching, learning, and research culture can emerge wherever an academic discipline enters into a constructive dialogue with the performing arts.

Many challenges of the 21st century (see the Sustainable Development Goals of the $\mathrm{UN})^{2}$ require creative solutions. Creativity is, however, not yet sufficiently promoted at universities, thus an artistic reorientation in teaching and research is imperative. As early as 2006, at the UNESCO World Congress in Lisbon and again in Seoul in $2010^{3}$, there were calls to strengthen the role of the arts in education. Implementation of these recommendations has, however, been very limited thus far.

Studies in cognitive science show that performative teaching and learning cultivates a deeper understanding of content and improved long-term retention of knowledge. ${ }^{4}$ In fact, it has been shown that the use of performative teaching and learning approaches leads to more creative, better learning outcomes; students relate more strongly to their studies and drop-out rates decrease. In addition, overall willingness to learn within the university context has been documented, as well as increased complexity and closer connection to practice in higher education, thus affording graduates better job placement opportunities.

At the 6th Scenario Forum Symposium in Hanover, Germany, September 21-22, 2018, the participants reflected on the theme: "Universities on the

\footnotetext{
${ }^{1}$ Claire Colebrook (2018): Foreword. In: Bryon, Experience (Hrsg.): Performing Interdisciplinarity. Working across disciplinary boundaries through an active aesthetic. London/New York: Routledge, $\mathrm{X}$.

${ }^{2}$ UNITED NATIONS - Sustainable Development Goals https://www.un.org/sustainabledevelopment/sustainable-development-goals/ [last accessed 20.10.2018].

3 UNESCO Roadmap for Arts Education 2006 -http://www.unesco.org/new/fileadmin/ MULTIMEDIA/HQ/CLT/CLT/pdf/Art_Ed_RoadMa_en.pdf [last accessed 30.09.2018].UNESCO - Second World Conference on Arts Education, 2010 - http://www.unesco.org/new/ en/culture/themes/creativity/arts-education/world-conferences/2010-seoul/ [last accessed 01.10.2018].

${ }^{4}$ See Arndt \& Sambanis (2017).
} 
way to a performative teaching, learning, and research culture?"5 Participating university educators and researchers described what constitutes a performative teaching, learning, and research culture as follows: ${ }^{6}$

- Educators allow themselves to be inspired by the performative arts, especially through theatre as a particularly integrative art form which promotes collaboration and synergies of abilities/intelligences. ${ }^{7}$

- The term "performative" emphasizes the implementation and execution/performance of actions in educational contexts, in particular the creative "doing" inspired by theatre. "Performative" contains both a reference to the FORMative, i.e. potential for personal development, as well as to the transFORMative, i.e. the potentially behavioural and attitude-changing dimension of teaching and learning.

- Particular attention should be paid to the open or specific FORM, in which teaching and learning takes place. ${ }^{8}$ Educators draw on the rich repertoire of sensory forms available through the arts.

- Educators and students alike do not only communicate orally, but also use additional means of expression, so that they are involved in the creative teaching and learning process with their "head, heart, hands and feet". The focus is no longer exclusively on results, but increasingly on the concrete teaching and learning activities from which lesson content is created.

- The ability to experience empathy through a change of role and perspective, for example by being in someone else's shoes in role, is of central importance.

- The educator initiates and supports democratic and participative learning processes and becomes a facilitator of learning processes, in which students take on responsibility as autonomous co-designers and co-creators.

- Competency is only fully acquired through practical application, i.e. experience. Performative approaches can be used to simulate authentic contexts.

- Knowledge acquisition requires space, i.e. an inspiring learning environment in which educators and students can freely move.

\footnotetext{
${ }^{5}$ Original title: Universitäten auf dem Wege zu einer performativen Lehr-, Lern- und Forschungskultur?

6 See also Even \& Schewe (2016).

7 Contemporary theater makers often examine the creative interplay of elements from various arts (e.g. Performance Art, Music, Visual Arts, Film, Dance, Literature).

${ }^{8}$ See Schewe \& Woodhouse (2018).
} 
- Sustainable learning requires time, i.e. an adequate pacing and distribution of topics and projects.

- Mistakes are seen as learning opportunities. This requires rethinking the definition of assessment, as it would then no longer focus on penalising mistakes.

- The whole world is a stage. A critical examination of the role of, and individual interaction with, (social) media in our performative societies (such as forms of self-portrayal on political stages and social media platforms) needs to be an integral part of 'performative literacy'. In this respect, a performative teaching, learning, and research culture aspires to democratic (intercultural / transnational) participation.

The participants of the 6th Scenario Forum Symposium in Hanover agreed on the following recommendations:

1. Teaching and learning in the context of higher education should follow the UNESCO recommendations for arts education. ${ }^{9}$

2. Discussions of a performative turn have been ongoing since the 1990s, especially in the social and cultural sciences. ${ }^{10}$ All disciplines are strongly encouraged to join the discussion of theory and practice that was initiated and strongly influenced by Linguistics, Gender Studies, and Theatre \& Performance Art.

3. University educators should strive to cooperate with artists in order to integrate artistic perspectives into the curriculum, as well as to plan joint performative public projects.

4. Convincing performative concepts, grounded in theory and practice, should be developed for teacher education and training, so that a 'performative teaching and learning culture' can emerge in all educational institutions. ${ }^{11}$

5. The extent to which innovative impulses from the performing arts have already permeated the various academic disciplines should be investigated, in order to determine to what extent performative teaching and learning practices are relevant to them. Efforts to bridge the gap between academic discipline-specific methodologies and the performing arts should be made, in order to increase respect and recognition of the performative in the higher educational contexts.

9 UNESCO Roadmap for Arts Education - http://www.unesco.org/new/fileadmin/ MULTIMEDIA/HQ/CLT/CLT/pdf/Art_Ed_RoadMa_en.pdf [last accessed 30.09.2018].

10 See Bachmann-Medick (2014).

11 See the thorough inventory by Fleiner (2016). 
6. 'Performative research' should be encouraged in various university disciplines. ${ }^{12}$ From a performative research perspective, the extent to which discipline-specific practice can be recognized as research should be examined. Furthermore, the extent to which research results can be presented in a non-discursive way should be studied.

This paper intends to encourage the creation of networks within or between universities, which will specifically promote performative teaching, learning, and research. ${ }^{13}$ It should, if possible, be forwarded to relevant professional associations and journals, as well as to colleagues in educational contexts outside of universities.

Translated from German by Eva Göksel

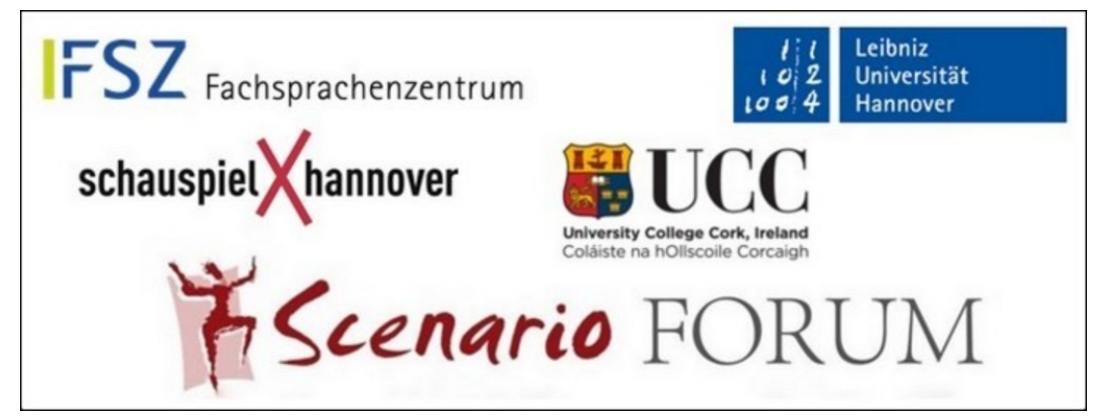

Remarks: Detailed information about the Programme of the $6^{\text {th }}$ Scenario Forum Symposium can be found here: https://www.fsz.uni-hannover.de/ scenarioforumsymposium. html [last accessed 30.09.2018].

We thank all those who have enriched the Symposium through lectures, presentations, workshops, discussions, as well as through any other contributions.

\section{Bibliography}

Arndt, Petra A. \& Sambanis, Michaela (2017): Didaktik und Neurowissenschaften - Dialog zwischen Wissenschaft und Praxis. Tübingen: Narr

Bachmann-Medick, Doris (2014): Cultural Turns: Neuorientierungen in den Kulturwissenschaften. Reinbek: Rowohlt

Colebrook, Claire (2018): Foreword. In: Byron, Experience (Hrsg.):

Performing Interdisciplinarity. Working across disciplinary boundaries through an active aesthetic. London/New York: Routledge, X

\footnotetext{
${ }^{12}$ For an overview of performative research see Haseman (2006).

13 We remember the contributions of many (now mostly retired) colleagues who were actively engaged in the university network "theatre in teaching" (active until about 2008).
} 
Even, Susanne \& Schewe, Manfred (2016): Performatives Lehren, Lernen, Forschen - Performative Teaching, Learning, Research. Berlin: Schibri

Fleiner, Micha (2016): Performancekünste im Hochschulstudium.

Transversale Sprach-, Literatur- und Kulturerfahrungen in der fremdsprachlichen Lehrerbildung. Berlin: Schibri

Haseman, Brad (2006): A Manifesto for Performative Research. In: Media International Australia incorporating Culture and Policy 118, 98-106. https://eprints.qut.edu.au/3999/1/399_1.pdf [letzter Zugriff 30.09.2018]

Schewe, Manfred \& Woodhouse, Fionn (2018): Performative Foreign Language Didactics in Progress: About Still Images and the Teacher as 'Formmeister' (Form Master). In: Scenario XII/1, 53-69

UNESCO Roadmap for Arts Education, 2006 http: / /www . unesco . org/ new/ fileadmin/MULTIMEDIA/HQ/CLT/CLT/pdf/Art_Ed_RoadMa_en.pdf [letzter Zugriff 30.09.2018]

UNESCO Second World Conference on Arts Education, 2010 http://www . unesco.org/new/en/culture/themes/creativity/artseducation/world-conferences/2010-seoul/ [letzter Zugriff 01.10.2018].

United Nations Sustainable Development Goals

https://www . un.org/sustainabledevelopment/sustainabledevelopment-goals/ [letzter Zugriff 20.10.2018] 